\title{
PREVALENCE OF ANAEMIA IN CHILDREN OF 6 MONTHS TO 59 MONTHS IN NARAYANGANJ, BANGLADESH
}

\author{
UDDIN MK ${ }^{1}$, SARDAR MH ${ }^{2}$, HOSSAIN MZ ${ }^{3}$, ALAM MM $^{4}$, BHUYA MF $^{5}$, UDDIN MM ${ }^{6}$, RAHMAN MJ $^{7}$
}

\begin{abstract}
:
Objective: To determine the prevalence of anaemia in children of 6 to 59 months old in Narayanganj, Bangladesh to help policy makers to formulate health and nutrition policies in national level.

Methods: In 2009, a representative sample of 767 young children lage ranging from 6 to 59 months) had their haemoglobin concentration measured. The sampling process was in three stages: at first, 5 Upazila hospitals, 1 District hospital and a 200 bedded specialized hospital were randomly selected to represent the whole district and its 5 geographic urban and rural areas. Next, using census lists, 15 census sectors were randomly chosen. Finally, 767 children of 6-59 months were selected. Blood was collected by vein puncture and haemoglobin concentration was measured with a haemoglobin meter. Data were analysed to determine prevalence of anaemia.

Results: The prevalence of anemia among the children of 5-59 months old was $40.9 \%$ for the district as a whole. Prevalence in the municipal region of Narayanganj was $40.9 \%$. The rural areas had the highest prevalence of 66.9\%. Prevalence was almost two times higher in children of 6-23 months in comparison to children of 24-59 months i.e. 61.8\% and 31.0\% respectively. The mean haemoglobin concentrations in the younger and older age groups were $10.4( \pm 1.5) \mathrm{g} /$ $\mathrm{dl}$ and $11.4( \pm 1.4) \mathrm{g} / \mathrm{dl}$ respectively. There is no difference found between the sexes.

Conclusion: This is the first assessment of anaemia prevalence among young children in Narayangaj, Bangladesh. As there is very high prevalence of anaemia among the children studied in Fatulla upazila, especially those in the age group 6-23 months, public health interventions are needed here most.
\end{abstract}

Key words: Anaemia, iron deficiency anaemia, haemoglobin, child heath, Bangladesh.

J Dhaka Med Coll. 2010; 19(2) : 126-130.

\section{Introduction:}

It is reported that 2170 million people are affected worldwide by nutritional anaemia. Out of these, $90 \%$ live in developing countries, and the countries of South Asian region have the highest prevalence of anaemia ${ }^{1}$. Iron deficiency anaemia is a public health problem in both developing and industrialized countries and more than 2 billion people around the world are estimated to have anaemia ${ }^{2}$. Prevalence of iron deficiency anaemia in developing countries as a whole is $36 \%$, and only $8 \%$ in developed countries ${ }^{3}$. The prevalence of anemia is high in women in reproductive age, $47 \%$ across the developing country and it worsens to $57 \%$ during pregnancy ${ }^{4}$. Most of the people of Narayanganj District of Bangladesh are lower middleclass and low income group and thus expected to have a high prevalence. This study was conducted to determine the prevalence of anaemia in Narayanganj and its 5 geographic areas. The study was focused on the prevalence of anaemia in a representative sample of children of 6-59 months.

\section{Materials and Methods:}

Narayanganj has an area of approximately 800 Sq. kilometer and a population of 2.7 million, of whom $10 \%$ are children under 5 years of age $^{5}$. The population of Narayanganj is predominantly urban. On the east, there is the Shitalaksha river and on the west and south, the Buriganga river. By the sides of the rivers, there are many small industries and many

1. Dr. Kazim Uddin, Consultant, 200 bedded Hospital, Narayanganj.

2. Dr. Md. Hafiz Sardar, Assistant Professor, Department of Medicine, Dhaka Medical Collage, Dhaka.

3. Dr. Mohammad Zaid Hossain, Assistant Professor, Department of Medicine, Dhaka Medical College, Dhaka.

4. Dr. Mahabubul Alam, Associate Professor, Department of Haematology, Sir Salimullah Medical Collage Hospital, Dhaka.

5. Dr. Md. Fakruddin Bhuya, Professor, Northern International Medical Collage Hospital, Dhaka.

6. Dr. Md. Moez Uddin, Consultant, 200 bedded Hospital, Narayanganj.

7. Prof. Md. Jalilur Rahman, Professor and Chairman, Dept. of Haematology, BSMMU, Dhaka.

Correspondence: Dr. Md. Kazim Uddin, Consultant, 200 bedded Hospital, Narayanganj. 
workers are living there with their families. Living condition is very poor, wages are low and amenities are few. In the towns, small industries and business centres provide employment. In Narayanganj, there are considerable differences in the quality of life within the district. The rural areas have the worst health and nutrition indices.

\section{Study design and data collection:}

The data were collected from January to June, 2010. The survey was cross sectional and sample was representative of the district and its 5 (five) geographic areas-the municipal regions, the urban and the rural interior. Sampling was carried out by systematic random sampling, permission of the mother and other custodian was first sought for blood collection. Venous blood was collected from an antecubital vein by trained pathology technician. The haemoglobin concentration was measured with portable haemoglobin meter by Sahli's method.

Date analysis:

Anemia was defined as a haemoglobin concentration $<11 \mathrm{~g} / \mathrm{dl}$. They are grouped as follows: severe anaemia, if $<7.0 \mathrm{~g} / \mathrm{dl}$; moderate anaemia, if $7.0 \mathrm{~g} / \mathrm{dl}$ to $8.9 \mathrm{gl} / \mathrm{dl}$ and mild anaemia, if 9.0 to $10.9 \mathrm{~g} / \mathrm{dl}^{6}$. We divided the age range of 6-59 months into five subgroups and weighed the overall prevalence for the district. In the statistical analysis, differences for categorical variables were assessed by the chi-square $\left(\mathrm{X}^{2}\right)$ test, and the $\mathrm{X}^{2}$ trend was used for linear trend.

\section{Results:}

Prevalence of Anaemia:

Table-I shows the prevalence of anaemia by age, sex and geographic area. Over all 40.9\% of children studied were anaemic. The highest prevalence was in the rural area $(51.4 \%)$. This was substantially higher $\left(X^{2}=\right.$ 13.77, $\mathrm{P}<0.001$ ) than in the municipal region $(39.6 \%)$ and urban interior $(35.9 \%)$. The prevalence of anaemia in children of 6-23 months old was twice as high as children of age $24-59$ months old i.e. $61.8 \%$ and $31.0 \%$ respectively. Anaemia prevalence was similar in boys and girls.

\section{Hemoglobin concentration:}

Table-II shows the mean haemoglobin concentrations by age, sex and geographic area. The over all mean value in children age 6-59 months was $10.9 \mathrm{gl} / \mathrm{dl}$. The mean value in rural area was $10.6 \mathrm{gl} / \mathrm{dl}$, compared with 11.0 $\mathrm{gl} / \mathrm{dl}$ for the municipal area Narayanganj and $11.2 \mathrm{gl} / \mathrm{dl}$ for urban area. The over all mean

Table-I

Prevalence of anaemia by age group and sex for the district as a whole and for geographic areas of Narayanganj

\begin{tabular}{|c|c|c|c|c|c|c|c|c|}
\hline $\begin{array}{l}\text { Age } \\
\text { group } \\
\text { (month) }\end{array}$ & $\begin{array}{l}\text { Children } \\
\text { in sub } \\
\text { group-No }\end{array}$ & $\begin{array}{c}\text { Anemia } \\
\text { prevalence } \\
(\%)\end{array}$ & $\begin{array}{l}\text { Children } \\
\text { in sub } \\
\text { group } \\
\text { (No) }\end{array}$ & $\begin{array}{c}\text { Anemia } \\
\text { Prevalence } \\
(\%)\end{array}$ & $\begin{array}{l}\text { Children } \\
\text { Sub } \\
\text { group } \\
\text { (No) }\end{array}$ & $\begin{array}{c}\text { Anemia } \\
\text { prevalence } \\
(\%)\end{array}$ & $\begin{array}{l}\text { Children } \\
\text { in sub } \\
\text { group (\%) }\end{array}$ & $\begin{array}{c}\text { Anemia } \\
\text { prevalence } \\
(\%)\end{array}$ \\
\hline 6-11 & 46 & 71.7 & 46 & 54.3 & 43 & 79.1 & 135 & 67.3 \\
\hline $12-23$ & 79.4 & 58.2 & 78.2 & 55.1 & 84.4 & 66.7 & 231 & 58.8 \\
\hline 24-35 & 49 & 44.9 & 43 & 23.3 & 56 & 57.1 & 148 & 38.8 \\
\hline $36-47$ & 59 & 23.7 & 44 & 22.7 & 32 & 21.9 & 135 & 22.9 \\
\hline $48-59$ & 45 & 13.3 & 35 & 34.3 & 38 & 34.2 & 118 & 25.8 \\
\hline Total & 274 & 39.6 & 244 & $35.9 \%$ & 249 & 51.4 & 767 & 40.9 \\
\hline \multicolumn{9}{|l|}{ Sex } \\
\hline Male & 140 & 43.3 & 130 & 38.9 & 120 & 56.1 & 390 & 45.8 \\
\hline Female & 134 & 43.8 & 114 & 42.6 & 129 & 56.2 & 767 & 47.6 \\
\hline
\end{tabular}

a. For age and geographic area, prevalence were weighted according to the actual population distribution in Narayanganj district as shown in data of $\mathrm{BBS}^{5}$.

b. Statistical difference between geographical areas: $\mathrm{X}^{2}=\mathrm{B} \cdot 77, \mathrm{P}<0.001$ 
Prevalence of Anaemia in Children of 6 Months to 59 Months

Uddin MK et al.

Table-II

Mean haemoglobin concentration $(\mathrm{g} / \mathrm{dl}$ ) and standard deviation (SD) by age group and sex for District as a whole and for geographic areas of Narayanganj

\begin{tabular}{|c|c|c|c|c|}
\hline & $\begin{array}{c}\text { Municipal area } \\
\text { (274 children) } \\
\text { Mean } \pm \text { SD }\end{array}$ & $\begin{array}{c}\text { Urban area } \\
\text { (244 children) } \\
\text { Mean } \pm \text { SD }\end{array}$ & $\begin{array}{c}\text { Rural area } \\
\text { (249 children) } \\
\text { Mean } \pm \text { SD }\end{array}$ & $\begin{array}{c}\text { Over all District } \\
\text { (767 children) } \\
\text { Mean } \pm \text { SD }\end{array}$ \\
\hline \multicolumn{5}{|c|}{ Age group } \\
\hline $6-11$ & $10.0 \pm 1.3$ & $10.8 \pm 1.2$ & $9.6 \pm 1.5$ & $10.1 \pm 1.4$ \\
\hline $12-23$ & $10.8 \pm 1.5$ & $10.6 \pm 1.4$ & $10.1 \pm 1.6$ & $10.5 \pm 1.5$ \\
\hline $24-35$ & $10.7 \pm 1.8$ & $11.6 \pm 1.0$ & $10.8 \pm 1.2$ & $11.0 \pm 1.5$ \\
\hline $36-47$ & $11.7 \pm 1.3$ & $11.8 \pm 1.5$ & $11.7 \pm 1.2$ & $11.7 \pm 1.4$ \\
\hline \multirow[t]{2}{*}{$46-59$} & $12.0 \pm 1.1$ & $11.6 \pm 1.5$ & $11.5 \pm 1.2$ & $11.7 \pm 1.3$ \\
\hline & $\mathrm{F}=15.55 \quad \mathrm{P}<0.001$ & $\mathrm{~F}=8.61 \mathrm{P}<0.001$ & $F=17.02 \quad P<0.001$ & $F=35.4 P<0.001$ \\
\hline Total & $11.0,1.6$ & $11.2, \quad 1.4$ & 10.6, 1.6, & $10.9, \quad 1.6$ \\
\hline \multicolumn{5}{|l|}{ Sex } \\
\hline $\begin{array}{l}\text { Male } \\
\text { Female }\end{array}$ & $\begin{array}{ll}11.1, & 1.7 \\
11.0, & 1.5,\end{array}$ & $\begin{array}{ll}11.2, & 1.6, \\
11.2, & 1.3,\end{array}$ & $\begin{array}{ll}10.6, & 1.5 \\
10.5, & 1.6\end{array}$ & $\begin{array}{lc}11.0, & 1.6 \\
10.9, & 1.5\end{array}$ \\
\hline & $\mathrm{t}=0.57 \quad \mathrm{P}=0.57$ & $\mathrm{t}=0.11 \quad \mathrm{P}=0.96$ & $\mathrm{t}=0.45 \quad \mathrm{P}=0.75$ & $\mathrm{t}=0.88 \quad \mathrm{P}=0.38$ \\
\hline
\end{tabular}

haemoglobin concentration was $1.0 \mathrm{gl} / \mathrm{dl}$ higher in children aged 24-59 months than it was among the young children in the study. The trend test by age was highly significant $(\mathrm{t}=$ $11.55, \mathrm{P}<0.001)$.

\section{Discussion:}

The over all anaemia prevalence that we found among the children of Narayanganj district is $40.9 \%$, indeed a public health concern. Particularly to be noted, the prevalence was $51.4 \%$ in the rural interior, $39.6 \%$ in the municipal region and $35.9 \%$ in the urban areas of Narayanganj. The main reasons for the differences we found between rural and urban areas are likely to be as lower consumption of iron in rural areas due to poverty, ignorance, illiteracy, low socio-economic condition, inappropriate family planning, poor sanitation and unsafe drinking water in rural area. Moreover, higher rates of parasitic diseases, leading to iron loss are also expected there ${ }^{6,7}$. Anaemia prevalence was twice as high in children 6-23 months old compared to those aged 24-59 months and similar findings have been reported by others ${ }^{8,9}$. Iron requirements are related to growth velocity and so requirement per $\mathrm{kg}$ of body weight decreases with age. Therefore, there may be a physiological explanation for the fall in anaemia prevalence with age. Iron intake is also likely to improve with age as a result of a more varied diet, including the introduction of meat and other iron containing foods. Infections depress iron absorption ${ }^{10}$ and the prevalence of infection is less in older children ${ }^{11}$. Thus, the significant decline in anaemia prevalence with age in population of Narayanganj is highly credible. Whether a single cut off of $11 \mathrm{~g} / \mathrm{dl}$ is appropriate for all age groups is debatable and some investigators have called age specific cut off ${ }^{12}$. "In normal" population, in which deficiency of iron, foliate and vitamin $\mathrm{B}_{12}$ have either been excluded or are unlikely, measurements of haemoglobin concentration give medium values for young children are about $12.5 \mathrm{~g} / \mathrm{dl}$ and a lower limit of normality of about $11.0 \mathrm{~g} / \mathrm{dl}^{12,13}$. Studies, however, also revealed a slow but gradual rise in haemoglobin concentration, starting from the age of 3 months. Dallman and Siimes ${ }^{13}$ reported that at 6 months of age, the lower level of normality of $11.1 \mathrm{~g} / \mathrm{dl}$, increasing to $11.3 \mathrm{~g} / \mathrm{dl}$ at 59 months. We used a cut off of $11.2 \mathrm{~g} / \mathrm{dl}$ (instead of $11 \mathrm{~g} / \mathrm{dl}$ ) for the age group of 24-59 months, the prevalence of anemia in this age group would 
be $33.3 \%$ rather than the $31.0 \%$ reported in table-I. This is a relatively small effect. A difference of $0.2 \mathrm{~g} / \mathrm{dl}$ between the two age groups, however, may be conservative, as larger changes with age were found by Brault et al. ${ }^{14}$. Sherriff et al. ${ }^{15}$ have recently suggested $10.0 \mathrm{~g} / \mathrm{dl}$ as the cut off for anemia in children aged 12-18 months based on the fifth centile for a large cohort study of children in the capital of United Kingdom. Their sample however, did not exclude iron-deficient children and the data may be unrepresentative of normal nonanaemic population ${ }^{12}$. Limitation of this study was some anemic individuals have hemoglobin concentration in the normal range and not been diagnosed, whereas, some normal individuals will be misclassified as anemia ${ }^{16}$. For these reasons, additional indicators of deficiency have been advocated, such as Serum ferritin, transferin saturation, erythrocyte protoporphyrin and $\mathrm{Hb}$-electrophoresis ${ }^{17,18}$. Multiple indicators however, are unusual in large population surveys ${ }^{17}$. Despite the difficulties in assessing anemia, we feel confident that the high prevalence of anaemia in Narayanganj district is evident and thus, interventions are warranted, and particularly needed for rural children and those of 6-24 months old. A potential intervention may be to use iron, vitamins and antihelminthic drugs. The national assistance program for malnourished pregnant women and children, educational interventions have the potential of being cost effective approaches for improving the health of young children. The aim would be to increase the varities of foods consumed, particularity foods rich in iron as well as the foods containing vitamin $\mathrm{C}$ at every meal ${ }^{18,19}$. Worms' burdens among those under 5 children are well known. Common parasites are Ascaris lumbricoids, Ankylostoma deudonalea and Trichuris trichura. These parasites cause blood loss in the stool and contribute to develop anaemia. Research to determine the prevalence of intestinal parasites among the children in urban and rural areas of Narayagnaj district is needed. Besides, interventions should be implemented, particularly deworming the children, supply of safe drinking water and proper disposal of human excreta.

\section{Acknowledgment:}

We are grateful to those mothers and their children who participated in this study as well as to the field health workers and medical technologists for their cooperation in our research.

\section{References:}

1. Seshadri S. Regional overview of the situational analysis of iron deficiency anemia for the inter country workshop on iron deficiency anemia. A report prepared to: STC/WHO, SEARO, New Delhi. India. 1995; by Dept. of Food \& Nutrition, University of Baroda, India.

2. United Nations Children's Fund. The state of the world's children. 1998; UNICEF House, New York, USA.

3. Dubcy AP. Iron deficiency anemia: epidemiology, diagnosis and clinical profile. In: Sachdev HPS, Choudhury P. eds. Nutrition in children Developing Country Concerns. $1^{\text {st }}$ ed. New Delhi: B. I. Publications; 1994.

4. De Maeyer EM, Adiels-Tegman M. The prevalence of anaemia in the world. World Health Statistics Quarterly. 1985; 38: 302-16.

5. Bureau of Statistics. Ministry of Health and Family Welfare. Government of the People's Republic of Bangladesh. 2005; Dhaka, Bangladesh.

6. De Maeyer EM, Dallman P, Gurney JM, Hallberg L, Sood SK, Srikantia SG. Preventing and controlling iron deficiency anemia through primary health care. A guide for health administrators and programme managers. 1989; World Health Organization (WHO), Geneva, Switzerland.

7. State Corporation. Statistics/data analysis (computer program). Version 5.0. 1997; College station. Texas, USA.

8. Dallman PR, Reeves JD. Laboratory diagnosis of iron deficiency. In: Stekel A. ed. Iron nutrition in infancy and childhood. Nestlé Nutrition Workshop Series, 4. New York: Raven Press; 1984. p. 11-44.

9. Karr M, Alperstain G, Cuser JC, Mira M. Iron status and anaemia in preschool children in Sydney. Aust NZ J Pub Health. 1996; 20(6): 61822 .

10. Beresford $\mathrm{CH}$, Neale RJ, Brooks OG. Iron absorption and pyrexia. Lancet. 1971; 1(7699): 568-72.

11. Guerrant RL, Kirchhoff LV, Shields DS, Nations MK, Leslie J, de Sousa MA, et al. Prospective study 
of diarrheal illnesses in northeastern Brazil: patterns of disease, nutritional impact, etiologies and risk factors. J Infect Dis. 1983: 148(6): 98697.

12. Viteri FE, de Tuna V, Guzman MA. Normal haematological values in the Central American population. Br J Haematol. 1972; 23(2): 189-204.

13. Dallman PR, Siimes MA. Percentile curves for hemoglobin and red cell volume in infancy and childhood. J Pediatr. 1979; 94(1): 26-31.

14. Brault-Dubuc M, Nadeau M, Dickie J. Iron status of French-Canadian children: a three-year followup. Hum Nutr Appi Nutr. 1983; 37A; 210-21.

15. Sherriff A, Emond A, Hawkins N, Golding J. Haemoglobin and ferritin concentrations in children aged 12 and 18 months. ALSPAC Children in Focus Study Team. Arch Dis Child. 1999; 80(2): 153-7.

16. Hercberg S, Galan P. Nutritional anaemias. Baillère's Clin Haematol. 1992; 5(1): 143-64.

17. Hercberg S, Chauliac M, Devanlay M, Galan P, Pureur JL, Soustre Y, et al. Evaluation of the iron status of a rural population in South Benin. Nutr Res. 1986; 6: 627-34.

18. Ashworth A, Feachem RG. Interventions for the control of diarrhoeal diseases among young children: weaning education. Bull World Health Organ. 1985; 63(6); 1115-27.

19. Yip R. The challenge of improving iron nutrition: limitations and potentials of major intervention approaches. Eur J Clin Nutr. 1997; 51: 516-24. 